\title{
IMPLEMENTASI PERATURAN MENTERI DESA NOMOR 3 TAHUN 2015 TENTANG PENDAMPINGAN DESA DI KANTOR DESA TELUK KECAPI KECAMATAN PEMULUTAN KABUPATEN OGAN ILIR
}

\author{
Oleh: \\ Citra Iasha, S.Psi.,M.Si \\ Dosen Sekolah Tinggi Ilmu Administrasi Satya Negara Palembang \\ Email : citraiasha09@gmail.com
}

\begin{abstract}
ABSTRAK
Pembangunan Desa adalah proses tahapan kegiatan yang diselenggarakan oleh Pemerintah Desa dengan melibatkan Badan permusyawaratan Desa dan unsure masyarakat secara partisipatif guna pemanfaatan dan pengalokasian sumber daya Desa dalam rangka mencapai tujuan Pembangunan Desa. Pemberdayaan Masyarakat Desa adalah upaya mengembangkan kemandirian dan kesejahteraan masyarakat dengan meningkatkan pengetahuan, sikap, keterampilan, perilaku, kebijakan, program, kegiatan, dan pendampingan sesuai dengan esensi masalah dan prioritas kebutuhan masyarakat Desa. Dalam melaksanakan Pembangunan dan Pemberdayaan Masyarakat Desa Menteri Desa PDTT Mengeluarkan dan menetapkan Peraturan Menteri Nomor 3 Tahun 2015 Tentang Pendempingan Desa.

Tujuan Penelitian ini adalah untuk mengetahui Implementasi Peraturan Menteri Desa Nomor 3 Tahun 2015 Tentang Pendampingan Desa di Kantor Desa Teluk Kecapi Kecamatan Pemulutan Kabupaten Ogan Ilir serta untuk mengetahui faktor-faktor apa sajakah yang menjadi penghambat dari Implementasi Peraturan Menteri Desa Nomor 3 Tahun 2015 Tentang Pendampingan Desa di Kantor Desa Teluk Kecapi Kecamatan Pemulutan Kabupaten Ogan Ilir. Metode Penelitian yang digunakan adalah Metode deskriptif kualitatif .Data atau informasi yang dikumpulkan melalui observasi dan wawancara terhadap informan.Teknik analisis data yang digunakan dalam penelitian ini menggunakan Reduksi Data, Penyajian Data serta Penarikan Kesimpulan.

Berdasarkan dari Hasil Penelitian menunjukkan bahwa Implementasi Peraturan Menteri Desa Nomor 3 Tahun 2015 Tentang Pendampingan Desa di Kantor Desa Teluk Kecapi Kecamatan Pemulutan Kabupaten Ogan Ilir masih belum terlaksana dengan baik, hal ini terlihat dari indikator-indikator implementasi yang dalam pelaksanaannya masih belum terealisasi dengan baik. Serta masih terdapatnya faktor-faktor pengahambat dalam pelaksanaan implementasi Peraturan Menteri Desa Nomor 3 Tahun 2015 Tentang Pendampingan Desa di Kantor Desa Teluk Kecapi Kecamatan Pemulutan Kabupaten Ogan Ilir.sehingga perlu adanya perbaikanperbaikan untuk mengatasi kendala-kendala tersebut.
\end{abstract}

Kata kunci: implementasi, pendampingan desa, 


\section{PENDAHULUAN}

Negara Republik Indonesia sebagai Negara Kesatuan menganut asas desentralisasi dalam menyelenggarakan pemerintahan dengan memberikan kesempatan dan keleluasan kepada daerah untuk menyelenggarakan otonomi daerah. Karena itu, Pasal 18 Undang-undang Dasar 1945 antara lain menyatakan bahwa pembagian Daerah Indonesia atas daerah besar dan kecil dengan bentuk dan susunan Pemerintahannya ditetapkan dengan undang - undang.

Daerah Indonesia akan dibagi dalam daerah Propinsi dan daerah Propinsi akan dibagi dalam daerah yang lebih kecil. di Daerah-daerah yang bersifat otonom akan diadakan Badan Perwakilan Daerah. Oleh karena itu, di daerah pun Pemerintahan akan bersendi atas Permusyawaratan.

Sejak Proklamasi Kemerdekaan tahun 1945 hingga sampai pada saat ini, peraturan-peraturan perundang yang mengatur tentang bentuk dan susunan Pemerintahan di daerah, termasuk Pemerintahan Desa adalah sebagai berikut :

a. Undang-undang Nomor 1 Tahun 1945 tentang Pembentukan Komite Nasional Daerah.

b. Undang-undang Nomor 22 Tahun 1948 tentang Pokok-pokok Pemerintahan Daerah.

c. Undang-undang Nomor 44 Tahun 1950 tentang Pokok-pokok Pemerintahan Daerah.

d. Undang-undang Nomor 1 Tahun 1957 tentang Pokok-pokok Pemerintahan Daerah.

e. Penetapan Presiden Nomor 6 Tahun 1959 tentang Pemerintahan Daerah (disempurnakan).

f. Penetapan Presiden Nomor 5 Tahun 1960 (disempurnakan) tentang DPRD Gotong Royong dan Sekretariat Daerah. g. Undang-undang Nomor 18 Tahun 1965 tantang Pokok-pokok Pemerintahan Daerah.

h. Undang-undang Nomor 19 Tahun 1965 tentang Desapraja.

a. Undang-undang Nomor 5 Tahun 1974 tentang Pokok-pokok Pemerintahan di Daerah.

i. Undang-undang Nomor 5 Tahun 1979 tentang Pemerintahan Desa.

j. Undang-undang Nomor 22 Tahun 1999 tentang Pemerintahan Daerah.

k. Undang-undang Nomor 25 Tahun 1999 tentang Perimbangan Keuangan Antara Pusat dan Daerah.

Desa adalah desa dan desa adat atau yang disebut dengan nama lain, selanjutnya disebut Desa, adalah kesatuan masyarakat hukum yang memiliki batas wilayah yang berwenang untuk mengatur dan mengurus urusan Pemerintahan, kepentingan masyarakat setempat berdasarkan prakarsa masyarakat, hak asal-usul, dan/atau hak tradisional yang diakui dan dihormati dalam sistem Pemerintahan Negara Kesatuan Republik Indonesia.

Pemerintahan Desa adalah penyelenggaraan urusan Pemerintahan dan kepentingan masyarakat setempat dalam sistem Pemerintahan Negara Kesatuan Republik Indonesia.Pemerintah Desa adalah Kepala Desa atau yang disebut dengan nama lain dibantu perangkat Desa sebagai unsur penyelenggara Pemerintahan Desa.

Badan Permusyawaratan Desa atau yang disebut dengan nama lain adalah lembaga yang melaksanakan fungsi Pemerintahan yang anggotanya merupakan wakil dari penduduk Desa berdasarkan keterwakilan wilayah dan ditetapkan secara demokratis. Unsur Masyarakat adalah kelompok-kelompok masyarakat Desa yang masing-masing kelompok memiliki kepentingan yang sama serta keterkaitan satu sama lain sebagai anggota kelompok. 
Musyawarah Desa atau yang disebut dengan nama lain adalah Musyawarah antara Badan Permusyawaratan Desa, Pemerintah Desa, dan unsur masyarakat yang diselenggarakan oleh Badan Permusyawaratan Desa untuk menyepakati hal yang bersifat strategis. Musyawarah Perencanaan Pembangunan Desa atau yang disebut dengan nama lain adalah Musyawarah antara Badan Permusyawaratan Desa, Pemerintah Desa, dan unsur masyarakat yang diselenggarakan oleh Pemerintah Desa untuk menetapkan prioritas, program, kegiatan, dan kebutuhan Pembangunan Desa yang didanai oleh Anggaran Pendapatan dan Belanja Desa, swadaya masyarakat Desa, dan atau Anggaran Pendapatan dan Belanja Daerah Kabupaten Kota.

Peraturan Desa adalah peraturan perundang-undangan yang ditetapkan oleh Kepala Desa setelah dibahas dan disepakati bersama Badan Permusyawaratan Desa.Pembangunan Desa adalah upaya peningkatan kualitas hidup dan kehidupan untuk sebesar-besarnya kesejahteraan masyarakat Desa.Perencanaan Pembangunan Desa adalah proses tahapan kegiatan yang diselenggarakan oleh Pemerintah Desa dengan melibatkan Badan Permusyawaratan Desa dan unsur masyarakat secara partisipatif guna pemanfaatan dan pengalokasian sumber daya Desa dalam rangka mencapai tujuan Pembangunan Desa.Kawasan Perdesaan adalah kawasan yang mempunyai kegiatan utama pertanian, termasuk pengelolaan sumber daya alam dengan susunan fungsi kawasan sebagai tempat permukiman perdesaan, pelayanan jasa Pemerintahan, Pelayanan Sosial, dan Kegiatan Ekonomi.Pembangunan partisipatif adalah suatu sistem pengelolaan pembangunan di Desa dan kawasan Perdesaan yang dikoordinasikan oleh Kepala Desa dengan mengedepankan

kebersamaan, kekeluargaan, dan kegotongroyongan guna mewujudkan perdamaian dan keadilan sosial.

Pemberdayaan Masyarakat Desa adalah upaya mengembangkan kemandirian dan kesejahteraan masyarakat dengan meningkatkan pengetahuan, sikap, keterampilan, perilaku, kemampuan, kesadaran, serta memanfaatkan sumber daya melalui penetapan kebijakan, program, kegiatan, dan pendampingan yang sesuai dengan esensi masalah dan prioritas kebutuhan masyarakat Desa.

Pendampingan Desa adalah kegiatan untuk melakukan tindakan Pemberdayaan Masyarakat melalui asistensi, Pengorganisasian, Pengarahan dan Fasilitasi Desa. Pemerintah Pusat selanjutnya disebut Pemerintah adalah Presiden Republik Indonesia yang memegang kekuasaan Pemerintahan Negara Republik Indonesia sebagaimana dimaksud dalam Undang-undang Dasar Negara Republik Indonesia Tahun 1945. Pemerintah Daerah adalah Pemerintah Daerah dan Dewan Perwakilan Rakyat Daerah yang menyelenggarakan urusan Pemerintahan menurut asas otonomi dan tugas pembantuan dengan Prinsip otonomi seluas-luasnya dalam sistem dan prinsip Negara Kesatuan Republik Indonesia Tahun 1945.

Sebagaimana diatur dalam Undangundang Nomor 22 Tahun 1999 dalam Bab XI Pasal 93-111 tentang Penyelenggaraan Pemerintahan Desa dan PP Nomor 76 Tahun 2001 tentang Pedoman umum Pengaturan mengenai Desa menekankan pada prinsip-prinsip Demokrasi, peran serta masyarakat, pemerataan serta keadilan serta memperhatikan potensi dan keanekaragaman Daerah. Dalam Pasal 94 Undang-undang Nomor 22 Tahun 1999, Bentuk Pemerintahan Desa terdiri atas Pemerintahan Desa dan Badan Perwakilan Desa dimana Pemerintahan Desa terdiri atas 
Kepala Desa dan Perangkat Desa ( Sekdes, Bendaharawan Desa, Kepala Seksi dan Kepala Dusun), sedangkan Badan Perwakilan Desa (BPD) sesuai Pasal 104 adalah wakil penduduk Desa yang dipilih dari dan oleh penduduk desa yang mempunyai fungsi mengayomi adatistiadat, membuat peraturan desa (Perdes), Dalam melaksanakan tugas dan kewajibannya, Kepala Desa bertanggung jawab kepada rakyat melalui Badan Perwakilan Desa dan Melaporkan pelaksanaan tugasnya kepada Bupati.

Kewenangan Desa mencakup kewenangan yang sudah ada berdasarkan hak asal-usul desa, kewenangan yang oleh peraturan perundang-undangan yang berlaku belum dilaksanakan oleh Daerah dan Pemerintah serta tugas pembantuan dari Pemerintah, Pemerintah Propinsi dan atau Pemerintah Kabupaten. Dalam membiayai penyelenggaraan Pemerintahan Desa telah diatur dalam Pasal 107 tentang sumber keuangan desa yang terdiri dari pendapatan asli desa, bantuan dari Pemerintah Kabupaten, Pemerintah Propinsi dan Pemerintah Pusat serta sumber Penerimaan dari pihak ketiga dan pinjaman Desa. Pendapatan Asli Desa (PAD) meliputi : hasil usaha desa, kekayaan desa, swadaya dan partisipasi serta gotong-royong dan lain-lain pendapatan desa yang sah.

Dalam melaksanakan penyelenggaraan pembangunan Desa dan pemberdayaan masyarakat Desa Menteri Desa Pembangunan Daerah Tertinggal dan Transmigrasi Republik Indonesia mengeluarkan dan menetapkan Peraturan Menteri Nomor 3 Tahun 2015 Tentang Pendampingan Desa. Tujuan Pendampingan Desa dalam Peraturan Menteri ini adalah :

a. Meningkatkan kapasitas, efektivitas dan akuntabilitas Pemerintahan Desa dan Pembangunan Desa. b. Meningkatkan prakarsa, kesadaran dan partisipasi masyarakat Desa dalam Pembangunan Desa yang partisipatif.

c. Meningkatkan sinergi program Pembangunan Desa antarsektor.

d. Mengoptimalkan aset lokal Desa secara emansipatoris.

Ruang Lingkup Pendampingan Desa meliputi :

a. Pendampingan masyarakat Desa dilaksanakan secara berjenjang untuk memberdayakan dan memperkuat Desa.

b. Pendampingan masyarakat Desa sesuai dengan kebutuhan yang didasarkan pada kondisi geografis wilayah, nilai APB Desa, dan cakupan kegiatan yang didampingi.

c. Pemerintah, pemerintah daerah provinsi, pemerintah daerah kabupaten/kota, dan Pemerintah Desa melakukan upaya pemberdayaan masyarakat Desa melalui pendampingan masyarakat Desa yang berkelanjutan, termasuk dalam hal penyediaan sumber daya manusia dan manajemen.

Pendamping Desa melaksanakan tugas mendampingi Desa, meliputi :

a. Mendampingi Desa dalam perencanaan, pelaksanaan, dan pemantauan terhadap pembangunan Desa dan pemberdayaan masyarakat Desa.

b. Mendampingi Desa dalam melaksanakan pengelolaan pelayanan sosial dasar, pengembangan usaha ekonomi Desa, pendayagunaan sumber daya alam dan teknologi tepat guna, pembangunan sarana dan prasarana Desa, dan pemberdayaan masyarakat Desa.

c. Melakukan peningkatan kapasitas bagi Pemerintahan Desa, lembaga kemasyarakatan Desa dalam hal pembangunan dan pemberdayaan masyarakat Desa.

d. Melakukan pengorganisasian di dalam kelompok-kelompok masyarakat Desa. 
e. Melakukan peningkatan kapasitas bagi Kader Pemberdayaan Masyarakat Desa dan mendorong terciptanya kader-kader pembangunan Desa yang baru.

f. Mendampingi Desa dalam pembangunan kawasan perdesaan secara partisipatif.

g. Melakukan koordinasi Pendampingan di tingkat kecamatan dan memfasilitasi laporan pelaksanaan pendampingan oleh Camat kepada Pemerintah Daerah Kabupaten / Kota.

Berdasarkan observasi di lapangan menunjukkan adanya indikasi Tugas Pendamping Desa Sesuai Peraturan Menteri Desa Nomor 3 Tahun 2015 dalam Penyelengaraan Pembangunan Desa dan Pemberdayaan Masyarakat Desa di Kantor Desa Teluk Kecapi Kecamatan Pemulutan Kabupaten Ogan Ilir masih terdapat banyak kekurangan, salah satu contohnya adalah Sumber daya Tenaga Pendamping Desa yang kinerjanya masih kurang maksimal seperti dalam pembuatan APBDes, RPJMDes, dan RKPDes seharusnya tugas pendamping Desa namun kenyataannya dilakukan oleh pegawai kantor Desa, serta keahlian Pendamping Desa tidak sesuai dengan kriteria yang dibutuhkan. Dari fenomena diatas maka penulis tertarik untuk mengambil judul Implementasi Peraturan Menteri Desa Nomor 3 Tahun 2015 Tentang Pendampingan Desa Di Kantor Desa Teluk Kecapi Kecamatan Pemulutan Kabupaten Ogan Ilir.

\section{TINJAUAN PUSTAKA}

\section{Pengertian Implementasi}

Implementasi diartikan sebagai pelaksanaan atau penerapan. Artinya yang dilaksanakan dan diterapkan sesuai tujuan yang telah terprogram sebelumnya dan kemudian dijalankan dengan sepenuhnya. Maka permasalahan besar yang akan terjadi apabila yang dilaksanakan bertolak belakang atau menyimpang dari program dan implementasinya. Menurut Usman (2002:70) Implementasi adalah : Bermuara pada aktivitas, tindakan atau adanya mekanisme suatu sistem. Implementasi bukan sekedar aktivitas, tetapi suatu kegiatan yang terencana dan untuk mencapai tujuan kegiatan.

Pengertian Implementasi yang dikemukakan diatas, dapat dikuatkan bahwa implementasi adalah bukan sekedar aktivitas, tetapi juga suatu kegiatan yang terencana dan dilakukan secara sungguhsungguh berdasarkan acuan norma tertentu untuk mencapai tujuan kegiatannya. Oleh karena itu, implementasi tidak bisa berdiri sendiri tetapi dipengaruhi oleh objek berikutnya.

$$
\text { Menurut Harsono (2002:67) }
$$

implementasi adalah : Suatu proses untuk melaksanakan kebijakan menjadi tindakan kebijakan dari politik kedalam administrasi. Pengembangan kebijakan dalam rangka penyempurnaan suatu program.

Berdasarkan pendapat diatas nampak bahwa implementasi tidak hanya terbatas pada tindakan atau perilaku badan eksekutif atau birokrasi yang bertanggung jawab untuk melaksanakan program dan menimbulkan kepatuhan dari target group. Namun lebih dari itu juga dengan jaringan kekuatan politik sosial dan ekonomi yang berpengaruh pada perilaku semua pihak yang terlibat dari pada akhirnya terdapat banyak dampak yang diharapkan maupun yang tidak diharapkan.

\section{Model - Model Implementasi Kebijakan Menurut Para Ahli}

Model-model Implementasi dapat digambarkan sebagai berikut (Agustino:142) :

a. Model Van Metter dan Van Horn "A Model of The Policy Implementation Process" 
Proses implementasi merupakan sebuah abtraksi atau performansi suatu implementasi kebijakan yang pada dasarnya secara sengaja dilakukan untuk meraih kinerja implementasi kebijakan publik yang tinggi yang berlangsung dalam hubungan berbagai variabel. Model ini mengandaikan bahwa implementasi kebijakan berjalan secara linier dari keputusan politik yang tersedia, pelaksana, dan kinerja kebijakan publik.

Ada enam variabel menurut Van Metter dan Van Horn yang mempengaruhi kinerja kebijakan publik, adalah :

1. Ukuran dan Tujuan Kebijakan.

2. Sumberdaya.

3. Karakteristik Agen Pelaksana.

4. Sikap/Kecenderungan (Disposition) para Pelaksana.

5. Komunikasi Antarorganisasi dan Aktivitas Pelaksana.

6. Lingkungan Ekonomi, Sosial dan Politik.

\section{Faktor Penghambat Implementasi}

Model-model Implementasi dapat digambarkan sebagai berikut (Agustino:142) :

Model Van Metter dan Van Horn "A Model of The Policy Implementation Process"

Proses implementasi merupakan sebuah abtraksi atau performansi suatu implementasi kebijakan yang pada dasarnya secara sengaja dilakukan untuk meraih kinerja implementasi kebijakan publik yang tinggi yang berlangsung dalam hubungan berbagai variabel. Model ini mengandaikan bahwa implementasi kebijakan berjalan secara linier dari keputusan politik yang tersedia, pelaksana, dan kinerja kebijakan publik.

Ada enam variabel menurut Van Metter dan Van Horn yang mempengaruhi kinerja kebijakan publik, adalah :

1. Ukuran dan Tujuan Kebijakan.
2. Sumberdaya.

3. Karakteristik Agen Pelaksana.

4. Sikap/Kecenderungan (Disposition) para Pelaksana.

5. Komunikasi Antarorganisasi dan Aktivitas Pelaksana.

6. Lingkungan Ekonomi, Sosial dan Politik.

Faktor Keberhasilan Dalam Implementasi

Menurut Van Meter dan Van Horn dalam (Agustino, 2012 : 142), ada enam variabel yang mempengaruhi kinerja Implementasi, yaitu :

1. Standart dan Sasaran Kebijakan

Setiap kebijakan publik harus mempunyai standart dan suatu sasaran kebijakan jelas dan terukur. Dengan ketentuan tersebut tujuannya dapat terwujudkan. Dalam standart dan sasaran kebijakan tidak jelas, sehingga tidak bias terjadi multi-interpretasi dan mudah menimbulkan kesalah-pahaman dan konflik diantara para agen implementasi.

2. Sumber Daya

Dalam suatu implementasi kebijakan perlu dukungan sumber daya, baik sumber daya manusia (human resources) maupun sumber daya materi (matrial resources) dan sumber daya metoda (method resources). Dari ketiga sumber daya tersebut, yang paling penting adalah sumber daya manusia, karena disamping sebagai subjek implemantasi kebijakan juga termasuk objek kebijakan publik.

3. Hubungan antar organisasi

Dalam banyak program implementasi kebijakan, sebagai realitas dari program kebijakan perlu hubungan yang baik antar instansi yang terkait, yaitu dukungan komunikasi dan koordinasi. Untuk itu, diperlukan koordinasi program tersebut. 
Komunikasi dan koordinasi merupakan salah satu urat nadi dari sebuah organisasi agar program-programnya tersebut dapat direalisasikan dengan tujuan serta sasarannya.

4. Karakteristik agen pelaksana

Dalam suatu implementasi kebijakan agar mencapai keberhasilan maksimal harus diidentifikasi dan diketahui karakteristik agen pelaksana yang mencakup struktur birokrasi, normanorma dan pola-pola hubungan yang terjadi dalam birokrasi, semua itu akan mempengaruhi implementasi suatu program kebijakan yang telah ditentukan.

5. Disposisi Implementator

Dalam implementasi kebijakan sikap atau disposisi implemntator ini dibedakan menjadi tiga hal, yaitu ; (a) respons implemntator terhadap kebijakan, yang terkait dengan kemauan implementator untuk melaksanakan kebijakan publi; (b) kondisi, yakni pemahaman terhadap kebijakan yang telah ditetapkan; dan (c) intens disposisi implemntator, yakni prferensi nilai yang dimiliki tersebut.

6. Kondisi lingkungan Sosial, Politik, dan Ekonomi

Variabel ini mencakup sumber daya ekonomi lingkungan yang dapat mendukung keberhasilan implementasi kebijakan, sejauh mana kelompokkelompok kepentingan memberikan dukungan bagi implementasi kebijakan; karakteristik para partisipan; bagaimana sifat opini publik yang ada di lingkungan dan apakah elite politik mendukung implentasi kebijakan.

\section{Peraturan Menteri Desa Nomor 3 Tahun2015}

Dalam mendorong terwujudnya Desa yang maju, kuat, mandiri, demokratis dan sejahtera, maka Kementerian Desa PDTT telah menerbitkan Peraturan Menteri Desa Pembangunan Daerah Tertinggal Nomor 3 Tahun 2015 tentang Pendampingan Desa. Untuk lebih jelasnya Menteri Desa Pembangunan Daerah Tertinggal telah membuat Peraturan tentang Pendampingan Desa di dalam Peraturan Menteri Nomor 3 Tahun 2015 yang isinya sebagai berikut :

Menteri Desa Pembangunan Daerah Tertinggal dan Transmigrasi Republik Indonesia

Menimbang :

Bahwa untuk melaksanakan ketentuan Pasal 131 ayat (1) Peraturan Pemerintah Nomor 43 Tahun 2014 tentang Peraturan Pelaksanaan Undang-undang Nomor 6 Tahun 2014 tentang Desa, perlu menetapkan Peratuaran Menteri Desa, Pembangunan Daerah Tertinggal, dan Transmigrasi tentang Pendampingan Desa;

\section{METODE PENELITIAN}

Teknik analisa data yang digunakan dalam penelitian ini adalah teknik analisis kualitatif. Penelitian yang menggunakan teknik analisis kualitatif bertujuan untuk menggali atau membangun suatu proposisi atau menjelaskan makna dibalik realita, dimana penelitian berpijak pada realita atau peristiwa yang terjadi dilapangan,

Selanjutnya, teknik analisis data yang digunakan dalam penelitian ini adalah analisis model interaktif (interactive model of analisys), berikut perincian untuk tahapan analisis model interaktif, yaitu :

1. Reduksi Data yaitu proses berfikir sensitif yang memerlukan kecerdasan dan keluasan serta kedalaman wawasan yang tinggi. Mereduksi data berarti merangkum, memilih hal-hal yang pokok, memfokuskan pada hal-hal yang 
penting, dicari tema dan pola serta membuang data yang tidak diperlukan.

2. Penyajian Data adalah menyajikan data kedalam bentuk uraian, bagan, hubungan antar kategori dan sejenisnya. Dalam penyajian data, informasi yang disajikan tersusun secara tertulis berdasarkan permasalahan fakta yang saling berkaitan.

3. Penarikan kesimpulan, setelah dilakukan reduksi data dan penyajian data langkah yang terakhir yang dilakukan peneliti adalah dapat mengambil kesimpulan. Kesimpulan tersebut merupakan pokok permasalahan yang diteliti di Kantor Desa Teluk Kecapi Kecamatan Pemulutan Kabupaten Ogan Ilir.

\section{HASIL PENELITIAN}

Bab ini akan diuraikan hasil penelitian peneliti beserta pembahasan permasalahan penelitian, permasalahan yang dihadapi peneliti adalah mengenai Bagaimanakah Implementasi Peraturan Menteri Desa Nomor 3 Tahun 2015 Tentang Pendampingan Desa di Kantor Desa Teluk Kecapi Kecamatan Pemulutan Kabupaten Ogan Ilir serta faktor-faktor yang menjadi penghambat dalam Pelaksanaan Pendampingan Desa di Kantor Desa Teluk Kecapi.

Berdasarkan hasil penelitian yang dilakukan bahwa pelaksanaan Peraturan Menteri Desa Nomor 3 Tahun 2015 Tentang Pendampingan Desa di Kantor Desa Teluk Kecapi Kecamatan Pemulutan Kabupaten Ogan Ilir belum terlaksana dengan baik, hal ini terlihat dari indikatorindikator implementasi yang dalam pelaksanaannya belum terealisasi dengan baik dan adanya faktor-faktor penghambat dalam pelaksanaan Pendampingan Desa di Kantor Desa Teluk Kecapi Kecamatan Pemulutan Kabupaten Ogan Ilir seperti Koordinasi antar Tenaga Pendamping Desa dengan Aparatur Pemerintahan Desa Teluk
Kecapi belum terealisasi dengan baik, dukungan Dana Anggaran Pemerintah Kabupaten maupun Dana Anggaran Pemerintah Pusat untuk biaya operasional Tenaga Pendamping yang masih belum berkesinambungan, Kurangnya Komunikasi antar Tenaga Pendamping Desa dengan Aparatur Pemerintahan Desa Teluk Kecapi, serta Sumber daya Tenaga Pendamping Desa yang kinerjanya masih kurang maksimal dalam pendampingan Desa di Desa Teluk Kecapi Kecamatan Pemulutan Kabupaten Ogan Ilir.

Peneliti melakukan penelitian dengan cara mendatangi langsung Kantor Desa Teluk Kecapi Kecamatan Pemulutan Kabupaten Ogan Ilir, dengan kegiatan melakukan observasi, wawancara, dokumentasi, kepustakaan, dan pengumpulan data yang berasal dari semua sumber yang ada memperoleh hasil penelitian tentang Implementasi Peraturan Menteri Desa Nomor 3 Tahun 2015 Tentang Pendampingan Desa di Kantor Desa Teluk Kecapi Kecamatan Pemulutan Kabupaten Ogan Ilir.

Telah dilakukan penelitian dalam menemukan atau menulusuri dari permasalahan yang terkait, adapun hasil penelitian merupakan data yang diolah berdasarkan teknik analisa data. Data diambil melalui wawancara dengan Kepala Desa Teluk Kecapi, Sekretaris Desa Teluk Kecapi, Ketua BPD Desa Teluk Kecapi, Staf Pegawai Desa Teluk Kecapi, serta para Tokoh-tokoh Masyarakat Desa Teluk Kecapi.

Berdasarkan hasil penelitian yang dilakukan bahwa pelaksanaan Peraturan Menteri Desa Nomor 3 Tahun 2015 Tentang Pendampingan Desa di Kantor Desa Teluk Kecapi Kecamatan Pemulutan Kabupaten Ogan Ilir belum terlaksana dengan baik, hal ini terlihat dari indikatorindikator implementasi yang dalam pelaksanaannya belum terealisasi dengan 
baik dan adanya faktor-faktor penghambat dalam pelaksanaan Pendampingan Desa di Kantor Desa Teluk Kecapi Kecamatan Pemulutan Kabupaten Ogan Ilir seperti Koordinasi antar Tenaga Pendamping Desa dengan Aparatur Pemerintahan Desa Teluk Kecapi belum terealisasi dengan baik, dukungan Dana Anggaran Pemerintah Kabupaten maupun Dana Anggaran Pemerintah Pusat untuk biaya operasional Tenaga Pendamping yang masih belum berkesinambungan, Kurangnya Komunikasi antar Tenaga Pendamping Desa dengan Aparatur Pemerintahan Desa Teluk Kecapi, serta Sumber daya Tenaga Pendamping Desa yang kinerjanya masih kurang maksimal dalam pendampingan Desa di Desa Teluk Kecapi Kecamatan Pemulutan Kabupaten Ogan Ilir.

Implementasi peraturan Menteri Desa Nomor 3 Tahun 2015 di Kantor Desa Teluk Kecapi Kecamatan Pemulutan Kabupaten Ogan Ilir dalam Pelaksanaan Pembangunan dan Pemberdayaan Masyarakat Desa masih belum terlaksana dengan baik, hal ini terlihat dari indikatorindikator Implementasi yang dalam pelaksanaannya belum terealisasi dengan baik serta masih terdapat adanya faktorfaktor penghambat dalam pelaksanaannya, seperti Kurangnya Koordinasi dan Komunikasi antar Tenaga Pendamping Desa dengan Aparatur Pemerintahan Desa, dukungan anggaran biaya operasional dari Pemerintah Pusat maupun Daerah yang tidak berkesinambungan, serta kurang maksimalnya kinerja dari tenaga Pendamping Desa dalam mendampingi Desa.

\section{Implementasi Peraturan Menteri Desa Nomor 3 Tahun 2015 Tentang Pendampingan Desa di Kantor Desa Teluk Kecapi Kecamatan Pemulutan Kabupaten Ogan Ilir}

Setiap kebijakan harus mempunyai standart dan suatu sasaran kebijakan jelas dan terukur. Dengan ketentuan tersebut maka tujuannya akan dapat terwujudkan. Seperti yang dikutip oleh Van Meter dan Van Horn (Agustino, 2012 : 142), Begitu juga dengan tugas tenaga Pendamping Desa semestinya harus adanya standart dan sasaran kebijakan yang jelas tepat sasaran dalam Pelaksanaan Kegiatan Pembangunan dan Pemberdayaan Masyarakat Desa. Dengan adanya standart serta sasaran kebijakan yang jelas dan terukur serta peningkatan kinerja lebih maksimal lagi dalam Pendampingan Desa di Desa Teluk Kecapi maka Pelaksanaan Kegiatan Pembangunan dan Pemberdayaan Masyarakat Desa di Desa Teluk Kecapi akan berjalan dengan baik dan sesuai dengan harapan.

Dalam suatu kebijakan perlu dukungan sumber daya, baik sumber daya manusia maupun sumber daya materi. Sejalan dengan pendapat Van Meter dan Van Horn (Agustino, 2012 : 142), Sumber daya manusia adalah kecukupan baik kualitas maupun kuantitas implementator yang dapat melingkupi seluruh kelompok sasaran. Sumber daya materi adalah kecukupan model investasi atau sebuah program/kebijakan. Keduanya harus diperhatikan dalam implementasi program/kebijakan pemerintahan. Sebab tanpa kehadiran implementator, kebijakan akan menjadi kurang enerjik dan berjalan lambat seadanya. Sedangkan, sumber daya materi menjamin keberlangsungan program/kebijakan. Tanpa adanya dukungan materi yang memadai, program tidak dapat efektif dan cepat dalam mencapai tujuan dan sasaran. Sumber daya tenaga Pendamping Desa khususnya Desa Teluk Kecapi sudah berjalan dengan baik dan terpenuhi hanya saja kurang maksimal nya kinerja dari para tenaga Pendamping Desa dalam mendampingi Desa Teluk 
Kecapi khususnya pada pelaksanaan kegiatan Pembangunan dan Pemberdayaan Masyarakat Desa serta dukungan materi harus lebih di optimalkan lagi supaya para tenaga Pendamping Desa lebih giat lagi dalam mendampingi Desa.

Sebagai realitas dari program kebijakan perlu adanya hubungan yang baik antar instansi yang terkait seperti tenaga Pendamping Desa dengan Aparatur Pemerintahan Desa. Komunikasi dan Koordinasi merupakan salah satu urat nadi dari sebuah organisasi agar programprogramnya tersebut dapat direalisasikan dengan tujuan serta sasarannya. Dalam melaksanakan kegiatan Pembangunan dan Pemberdayaan Masyarakat Desa hubungan antar organisasi baik dari tenaga Pendamping Desa dengan Aparatur Pemerintahan Desa sangat diperlukan seperti pengawasan dan pendampingan dari tenaga Pendamping Desa terhadap pelaksananaan, perencanaan serta pertanggungjawabannya agar Kegiatan Pembangunan dan Pemberdayaan Masyarakat di Desa Teluk Kecapi berjalan sesuai dengan harapan.

$$
\text { Pada setiap Implementasi }
$$

Kebijakan agar mencapai keberhasilan maksimal harus diidentifikasi dan diketahui karakteristik agen pelaksana yang mencakup struktur birokrasi, norma-norma dan pola-pola hubungan yang terjadi dalam birokrasi. seperti yang di katakan oleh Van Meter dan Van Horn (Agustino, 2012 : 142), Begitu juga dengan Pelaksanaan Kegiatan Pembangunan dan Pemberdayaan Masyarakat khususnya di Desa Teluk Kecapi para Tenaga Pendamping Desa maupun Aparatur Pemerintahan Desa harus memiliki karakter yang menunjang dan jiwa kesadaran yang membangun, karena semua itu akan mempengaruhi keberhasilan dalam Pelaksanaan Kegiatan Pembangunan dan Pemberdayaan Masyarakat Desa di Desa
Teluk Kecapi Kecamatan Pemulutan Kabupaten Ogan Ilir.

Disposisi Implementator sangat berperan penting dalam suatu Implementasi Kebijakan. Begitu juga dengan Disposisi para tenaga Pendamping Desa dengan Aparatur Pemerintahan Desa sangat berpengaruh terhadap keberhasilan dari pelaksanaan kegiatan Pembangunan dan Pemberdayaan Masyarakat Desa di Desa Teluk Kecapi sehingga pada saat pelaksanaannya akan tepat waktu dan tidak akan menghambat keberhasilan dari pelaksanaan Pembangunan dan Pemberdayaan Masyarakat di Desa Teluk Kecapi Kecamatan Pemulutan Kabupaten Ogan Ilir.

Kondisi Lingkungan Sosial, Politik, dan Ekonomi variabel ini mencakup sumber daya ekonomi lingkungan yang dapat mendukung keberhasilan Implementasi Kebijakan, sejauh mana kelompokkelompok kepentingan memberikan dukungan bagi Implementasi Kebijakan, Karakteristik para partisipan, bagaimana sifat opini publik yang ada di lingkungan dan para elite politik mendukung Implementasi Kebijakan. Seperti yang dikemukakan oleh Van Meter dan Van Horn (Agustino, 2012 : 142), Dalam pelaksanaan Kegiatan Pembangunan dan Pemberdayaan Masyarakat Desa Kondisi Lingkungan Sosial, Politik, dan Ekonomi di Desa Teluk Kecapi sangat positif respon masyarakatnya bahkan dengan adanya Pendampingan Desa dari tenaga Pendamping Desa dalam Pelaksanaan Kegiatan Pembangunan dan Pemberdayaan Masyarakat Desa di Desa Teluk Kecapi tingkat Percepatan Pembangunan dan Keseajahteraan Masyarakat Desa akan menjadi lebih baik melalui programprogram Desa yang sudah ditetapkan dalam Rencana Kerja Pemerintahan Desa dan Rencana Pembangunan Jangka Menengah Desa. 
Pendamping Desa juga sangat dibutuhkan perannya dalam mendampingi Desa pada saat Perencanaan Pembangunan dan Keuangan Desa maupun pada saat Pelaksanaan Kegiatan Pembangunan dan Pemberdayaan Masyarakat Desa, begitupun dalam pemantauan serta evaluasi setiap tahunnya agar pelaksanaan kegiatan Pembangunan dan Pemberdayaan Masyarakat di Desa Teluk Kecapi Kecamatan Pemulutan Kabupaten Ogan Ilir berjalan dengan baik dan sesuai harapan.

\section{Faktor-Faktor \\ Penghambat Implementasi Peraturan Menteri Desa Nomor 3 Tahun 2015 Tentang Pendampingan Desa di Kantor Desa Teluk Kecapi Kecamatan Pemulutan Kabupaten Ogan Ilir}

Pelaksanaan suatu kebijakan akan sangat sulit apabila pada pengimplementasiannya tidak cukup dukungan untuk pelaksanaan kebijakan tersebut seperti yang dikemukakan oleh Sunggono (2010:149), begitu juga dalam Pelaksanaan Pendampingan Desa di Kantor Desa Teluk Kecapi Kecamatan Pemulutan Kabupaten Ogan Ilir sesuai dengan Peraturan yang sudah ditetapkan oleh Menteri Desa Pembangunan Daerah Tertinggal dan Transmigrasi Republik Indonesia masih terdapat beberapa hal-hal yang menjadi penghambat, yaitu Koordinasi serta Komunikasi dari Tenaga Pendamping Desa dengan Aparatur Pemerintahan Desa Teluk Kecapi masih belum terealisasi dengan baik pada saat Perencanaan, Pelaksanaan serta pertanggungjawaban Kegiatan Pembangunan dan Pemberdayaan Masyarakat Desa. sebaiknya Kepala Desa Teluk Kecapi memberikan inisiatif atau pengarahan kepada Tenaga Pendamping Desa untuk lebih meningkatkan lagi Koordinasi dan Komunikasi yang lebih baik lagi dengan Aparatur Pemerintahan
Desa Teluk Kecapi agar dalam Pelaksanaan serta pertanggungjawaban Kegiatan Pembangunan dan Pemberdayaan Masyarakat di Desa Teluk Kecapi berjalan dengan baik sesuai harapan.

Penyebab dari timbulnya kegagalan Implementasi suatu kebijakan terjadi karena kekurangan-kekurangan yang menyangkut waktu, biaya atau tenaga manusia seperti yang di kemukakan oleh Sunggono (2010:149), Begitupun juga pada pelaksanaan Pendampingan Desa di Desa Teluk Kecapi Kecamatan Pemulutan Kabupaten Ogan Ilir, masih kurangnya dukungan Anggaran dari Pemerintah Daerah maupun Pusat yang tidak berkesinambungan sehingga dapat menghambat kinerja dari para Tenaga Pendampingan Desa. seharusnya Kepala Desa beserta staf dan jajarannya mengusulkan ketetapan anggaran biaya untuk operasional Tenaga Pendamping Desa dan Aparatur Pemerintahan Desa dari Dana Bantuan Anggaran Pemerintah Daerah maupun dari Bantuan Anggaran Pemerintah Pusat agar kinerja Pendamping Desa dan Aparatur Pemerintahan Desa dalam Pelaksanaan Pendampingan Kegiatan Pembangunan dan Pemberdayaan Masyarakat di Desa Teluk Kecapi berjalan dengan baik.

Gagalnya Implementasi suatu kebijakan ditentukan aspek pembagian potensi diantaranya para pelaku yang terlibat dalam Implementasi dalam hal ini berkaitan dengan diferensiasi tugas dan wewenang organisasi pelaksana sejalan dengan pendapat yang dikemukakan oleh Sunggono (2010:149), Seperti kinerja dari para Tenaga Pendamping Desa yang masih kurang maksimal dalam mendampingi Desa Teluk Kecapi Kecamatan Pemulutan Kabupaten Ogan Ilir ini akan menghambat dari keberhasilan Pelaksanaan Kegiatan Pembangunan dan Pemberdayaan Masyarakat di Desa Teluk Kecapi 
Kecamatan Pemulutan Kabupaten Ogan Ilir. Sebaiknya Kepala Desa memberikan intruksi dan penegasan kepada Tenaga Pendamping Desa agar dalam tugas dan fungsinya lebih maksimal lagi khususnya dalam mendampingi Desa Teluk Kecapi Kecamatan Pemulutan Kabupaten Ogan ilir pada Kegiatan Pelaksanaan Pembangunan dan Pemberdayaan Masyarakat Desa di Desa Teluk Kecapi Kecamatan Pemulutan Kabupaten Ogan Ilir.

\section{KESIMPULAN}

Berdasarkan hasil penelitian maka penulis dapat mengambil kesimpulan yaitu sebagai berikut :

1. Pelaksanaan Peraturan Menteri Desa Nomor 3 Tahun 2015 Tentang Pendampingan Desa di Kantor Desa Teluk Kecapi Kecamatan Pemulutan Kabupaten Ogan Ilir masih belum terlaksana dengan baik, hal ini terlihat dari indikator-indikator Implementasi yang dalam pelaksanaanya masih belum terealisasi dengan baik. Seperti Standart dan sasaran kebijakan yang masih belum tepat dan terukur, kurang terpenuhinya sumberdaya manusia dan sumber daya materi yang tidak berkesinambungan, hubungan antar organisasi yang masih belum terealisasi dengan baik, karakteristik agen pelaksana yang dalam pelaksanaannya masih kurang maksimal, serta tidak tepatnya disposisi implementator dari para pelaksana kebijakan.

2. Faktor yang menjadi penghambat Implementasi Peraturan Menteri Desa Nomor 3 Tahun 2015 Tentang Pendampingan Desa di Kantor Desa Teluk Kecapi Kecamatan Pemulutan Kabupaten Ogan Ilir adalah Kurangnya Koordinasi dan Komunikasi antar Tenaga
Pendamping Desa dengan Aparatur Pemerintahan Desa Teluk Kecapi, dukungan Anggaran Biaya Operasional dari Pemerintah Pusat Maupun Daerah yang tidak berkesinambungan, serta sumber daya tenaga Pendamping Desa yang kinerjanya masih kurang maksimal dalam mendampingi Desa di Desa Teluk Kecapi Kecamatan Pemulutan Kabupaten Ogan Ilir.

\section{DAFTAR PUSTAKA}

Agustino, 2012. Dasar - Dasar Kebijakan Publik. Bandung Alfabeta.

Harsono, 2002. Implementasi Kebijakan dan Politk. Jakarta : Rineka Cipta.

Widjaja, 2002. Otonomi Desa. Jakarta : PT. Rajagrafindo Persada

Meleong, 2006. Metodologi Penelitian Kualitatif. Bandung : Remaja Rosadakarya.

Usman, 2002. Konteks Implementasi Berbasis Kurikulum. Bandung : CV.Sinar Baru.

Singarimbun, 2011. Metode Penelitian. Jakarta : PT. Rineke Cipta.

Sunggono, 2010. Hukum dan Kebijaksanaan Publik. Jakarta : Sinar Grafika

Sugiyono, 2011. Metode Penelitian Pendidikan. Bandung : Alfabeta 